GOV. R. E. FENTON AND GEO. A. S. CROOKER.

Readers whose memories go back to the rebellion will readily recall the name of War-Governor Reuben E. Fenton, of New York, who was afterwards a United States Senator, and at one time quite prominently mentioned for President of the United States. He was orginally a Dem- ocrat, belonging to the anti-slavery wing of the party. In his congressional district (Cattaraugus and Chautauqua counties) the Whigs had a majority of about 2,000. One George A. S. Crooker, a Whig and a lawyer of very distinguished ability-but a man whose private character was deemed unsatisfactory-could always control his home delegation, but Chauliauqua would have none of him. Finally, however, after years of manipulation, he secured the nomination for Member of Congress. This was Fenton's opportunity. The Democratic nomination was freely accorded to him, and he was triumphantly chosen by 200 majority, sweeping away the 2,000 Whig majority as with a new broom. His after career made his name illustrious. But poor Crooker was extinguished-his fond, long-cherished hopes terribly blasted. He came west, stopping for a time in Chicago where he became noted as a spiritualist. His "last appearance on any stage" was in Cerro Gordo Co., Iowa, whither "the spirits" sent or directed him to pros. pect for coal. But as to whether he was to find anthracite or bituminous coal the legend is silent. It is said that he sunk a shaft some eighty feet deep, on section 16 , in the $\mathrm{S}$. W. township of Cerro Gordo county, but was only rewarded by developing a fine flowing well. This was in a region geologically far below the carboniferous formation--a fact unknown to or ignored by "the spirits." Crooker did not long survive this last disappointment, and died in poverty and neglect. He was a very handsome man fifty years ago (as the writer well remembers), an eloquent spealk- 
er, a brilliant lawyer, quite gifted as a wit and a poet, and for more than a quarter of a century the most influential citizen of Cattaraugus county. Many "believed in him," and not a few imagined that when "he strode abroad "the earth trembled."

"But passed is all his fame: The very spot

Where many a time heltriumphed is forgot."

\section{THE EARLY NAMES OF COUNCIL BLUFFS.}

Hon. D. C. Bloomer, the distinguished pioneer, educator and ex-mayor, of Council Bluffs, was lately asked to give some account of the names by which that now flourishing city was known in its infancy, and more especially that of "Kanesville," which appears in early records and laws. He replied to this request in the follow. ing interesting and valuable letter:

Council BLuffs, Iowa, MAY 25, 1896.

My Deaŕsir: I do not think that the name "Kanesville" was ever established by any legislative authority in Iowa. This locality was first given the name, in the very early days, of "Hart's Bluff;" next of. "Miller's Hollow," and next of "Kanésville." This name was derived from Col. Kane, of Pennsylvania, wholcame here in the very early days of 1846, and was a great friend of the Mormons. He mustered the "Mormon Battalion" into the United States service in that year. In honor of him the Mormons gave their town the name of "Kanesville," and a post-office was established here in 1848, and Evan M. Green made Postmaster. The District Court was first opened here in 1851. In these authoritative acts, both of the General and State Governments. the name of "Kanesville" was recognized and so continued to be until it was changed to "Council Bluffs,". by the General $\Delta$ ssembly early in 1853. (See Acts and resolutions of the Fourth General Assembly, chiapter 43, page 72.) Since then, the name of "Kanesville" has benn dropped, except among some of the old settlers who occasionally use it. While the Indians were here no other name seems to have been used, so far as I. can find, other than "Miller's Hollow" or "Traders' Point." Just what name was used by the General Government in its transactions with the Indians I cannot determine; but possibly you may be able to settle that point by documents in your historical collection.

Both the State and General Government simply recognized the name "Kanesville," beginuing with 1846 , when that name was first applied to this locality.

Charies Aldrich, Esq. Yours very truly,

D. C. BLOOMER. 
Copyright of Annals of Iowa is the property of State of Iowa, by \& through the State Historical Society of Iowa and its content may not be copied or emailed to multiple sites or posted to a listserv without the copyright holder's express written permission. However, users may print, download, or email articles for individual use. 